\title{
Population dynamics of an endemic and threatened Yellow Catfish Horabagrus brachysoma (Günther) from Periyar River, southern Western Ghats, India
}

\author{
G. Prasad ${ }^{1}$, Anvar $\mathrm{Ali}^{2}$, M. Harikrishnan ${ }^{3}$ \& Rajeev Raghavan ${ }^{4,5}$ \\ ${ }^{1,2}$ Laboratory of Conservation Biology, Department of Zoology, University of Kerala, Kariavattom, Thiruvananthapuram, Kerala \\ 695581 , India \\ ${ }^{3}$ School of Industrial Fisheries, Cochin University of Science and Technology, Kochi, Kerala 682016, India \\ ${ }^{4}$ Conservation Research Group (CRG), St. Albert's College, Kochi, Kerala 682018, India \\ ${ }^{5}$ Durrell Institute of Conservation and Ecology (DICE), School of Anthropology and Conservation, University of Kent, Canterbury, \\ CT2 7NR, United Kingdom \\ Email: ${ }^{1}$ probios2003@yahoo.co.in (corresponding author), ${ }^{2}$ anvaraliif@gmail.com, ${ }^{3}$ mahadevhari@hotmail.com, \\ ${ }^{4}$ rajeevraq@hotmail.com
}

\begin{abstract}
Based on the annual length frequency data collected from three major fish landing centres along the River Periyar, draining the southern Western Ghats, the von Bertalanffy growth function (VBGF) estimates of Horobagrus brachysoma were worked out as asymptotic length $\left(L_{a}\right)=422 \mathrm{~mm}$ total length, growth co-efficient $(K)=0.55 \mathrm{yr}^{-1}$ and growth performance index $(\varnothing)=4.99$. The total mortality rate $(Z)$ was estimated at $5.64 \mathrm{yr}^{-1}$, natural mortality rate $(\mathrm{M})$ at $1.04 \mathrm{yr}^{-1}$, fishing mortality $(\mathrm{F})$ at $4.60 \mathrm{yr}^{-1}$, and exploitation rate (E) at $0.82 \mathrm{yr}^{-1}$. Yield per recruit (expected lifetime yield per fish recruited in the stock at a specific age) analysis showed an excessive fishing effort. Using the analysis of probability of capture of each length class, the length at first capture $\left(L_{c}\right)$ of $H$. brachysoma was estimated to be $110 \mathrm{~mm}$. An indication of both growth and recruitment fishing is provided by the dominance of year 1 class in the exploited population and the capture of immature individuals below first maturity. Management of $H$. brachysoma fishing should include setting of a minimum mesh size limit of $160-180 \mathrm{~mm}$ for gill nets as well as a closed season starting from the month of May till August aimed at protecting the spawning stock. This study on $H$. brachysoma, an endemic and threatened catfish of peninsular India, provides hard evidence that species targeted by artisanal fishermen, in small-scale tropical riverine fisheries, are vulnerable to overexploitation.
\end{abstract}

Keywords: Artisanal fishery, Horabagrus brachysoma, overfishing, small-scale fishery, threatened species

Date of publication (online): 26 February 2012 Date of publication (print): 26 February 2012 ISSN 0974-7907 (online) | 0974-7893 (print)

Editor: Anonimity requested

Manuscript details:

Ms \# 02590

Received 29 September 2010

Final received 03 January 2012

Finally accepted 30 January 2012

Citation: Prasad, G., A. Ali, M. Harikrishnan \& R. Raghavan (2012). Population dynamics of an endemic and threatened Yellow Catfish Horabagrus brachysoma (Günther) from Periyar River, southern Western Ghats, India. Journal of Threatened Taxa 4(2): 2333-2342.

Copyright: (C) G. Prasad, Anvar Ali, M. Harikrishnan \& Rajeev Raghavan 2012. Creative Commons Attaribution 3.0 Unported License. JoTT allows unrestricted use of this article in any medium for non-profit purposes, reproduction and distribution by providing adequate credit to the authors and the source of publication.

Author Details, Author Contribution and Acknowledgements: See end of this article.

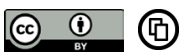

OPEN ACCESS | FREE DOWNLOAD

\section{INTRODUCTION}

Small scale freshwater fisheries contribute an important source of food security and livelihood to billions of rural communities in the tropics. However, lack of fundamental data on such fisheries has led to failures in management aimed at preventing overexploitation, population decline, and their impact on local livelihoods. Meanwhile, overfishing has currently become an important driver of biodiversity loss in inland waters (Allan et al. 2005) and decline in population of many species are occurring concomitantly with the increase in global inland fish production. In Asia, the world's largest inland fish producing region, wild caught freshwater fisheries have been showing signs of overexploitation with declines in catch per unit effort, age at maturity and also the average size of fishes caught (Dudgeon 2000). In spite of being small-scale and artisanal in nature, the fishery of several important freshwater fish including mahseer (Bhatt et al. 2000, 2004; Raghavan et al. 2011) and catfish (Patra et al. 2005) in India; major carps (de Graaf 2003) in Bangladesh; large cyprinids in the Mekong basin (Baird 2006; Dudgeon 2000) and sturgeons in China (Wei et al. 1997) have shown a characteristic decline in the last decade.

Exhaustive information is currently available on the demography, population regulation and exploitation patterns of large numbers of marine fish species. However, unlike marine ecosystems, datasets on the 
dynamics of exploited populations of economically important fish species in rivers, especially those in the developing countries are largely unavailable. This is mainly due to the lack of personnel and financial resources in such countries to undertake research programs (Maccord et al. 2007). These deficiencies are also a cause and consequence of the lack of attention that the sector receives from the government (Anonymous 2002).

As with other small rivers in Asia, Periyar-a 244-km long river in the southern Indian state of Kerala-supports a lucrative inland fishery, largely based on cyprinids and catfish. This fishery, mainly concentrated in the lower stretches of the river is predominantly artisanal. The Yellow Catfish Horabagrus brachysoma is one such species which is targeted frequently by the traditional fishermen of Periyar River using gill nets (odakku vala; Malayalam) operated from canoes and also by using hooks and lines. Known locally as 'manjakoori', the Yellow Catfish grows to a size of $450 \mathrm{~mm}$ (Talwar \& Jhingaran 1991) and is a gourmet's delight. Fingerlings of $H$. brachysoma, due to their vibrant yellow coloration are also becoming increasingly popular in the international aquarium pet trade (Raghavan 2006). A multitude of stressors including overexploitation, habitat alteration and pollution has, however, resulted in the population decline of $H$. brachysoma in its native ranges, with the fish getting listed as Vulnerable in the IUCN Red List of Threatened Species (Raghavan \& Ali 2011). The peculiar life history traits of the species, including a medium resilience to overfishing and a minimum population doubling time of 1.4 to 4.4 years (Froese \& Pauly 2009) also makes this species vulnerable to the overfishing. In spite of its threatened status, declining numbers and specific life history traits, exploitation of $H$. brachysoma for both the food and ornamental markets continues unabated (Ali et al. 2007).

In Vembanad Lake, which is an extensive system of backwaters (and a Ramsar wetland) into which Periyar and five other river systems drain, $H$. brachysoma is the focus of organized artisanal gill net fishery (Raghavan 2006). Landings of the Yellow Catfish in Vembanad Lake have shown a wavy trend from 1995 until 2004, having increased and decreased every few years (Kurup et al. 1995; Bindu 2006; Sreeraj et al. 2007). Despite early reports of the serious population declines of $H$. brachysoma and co-occurring catfish species in the Vembanad Lake (Kurup et al. 1993), no effort hitherto has been made to assess the dynamics of these exploited stocks from either the lake, or from other water bodies of the state. This paper is the first comprehensive study on the population dynamics of this species.

\section{MATERIALS AND METHODS}

\section{Study site}

River Periyar has a total catchment area of $5243 \mathrm{~km}^{2}$ and a length of about $300 \mathrm{~km}$ (Smakhtin et al. 2009). For a small-sized basin, Periyar nevertheless harbours a number of endemic and threatened species (Molur \& Walker 1998; Kurup et al. 2006) which is approximately $70 \%$ of the fish species present in the Western Ghats Hotspot (Smakhtin et al. 2009). The present study was concentrated on the lower stretches of the Periyar River between $76^{0} 10^{\prime}-76^{\circ} 23^{\prime} \mathrm{N}$ \& $10^{\circ} 98^{\prime}-10^{\circ} 73^{\prime} \mathrm{E}$ (Fig. 1) where H. brachysoma is known to be fished intensively.

\section{Data collection}

The total length $(\mathrm{mm})$ and weight $(\mathrm{g})$ data of $H$. brachysoma subsamples were measured from wellmixed catches of six to 10 fishermen, operating from three major fish landing centres, namely, Kalady $\left(76^{0} 19^{\prime} \mathrm{N} \& 10^{\circ} 10^{\prime} \mathrm{E}\right)$, Angadikadavu (76 $23^{\prime} \mathrm{N}$ \& $\left.10^{\circ} 73^{\prime} \mathrm{E}\right)$ and Manjaly $\left(76^{\circ} 10^{\prime} \mathrm{N} \& 10^{\circ} 98^{\prime} \mathrm{E}\right)$, located in the lower stretches of Periyar River, from January to December 2005. Since males and females were easily distinguishable, they were identified by their big, soft and distended belly with swollen and reddish-pink vent (females) and reddish genital opening (males). Measures of 2638 males and 3382 females were taken for the study. No fish were collected or sacrificed for the purpose of the study. Sampling was carried out twice in each month during the first quarter moon and full moon. Data was collected following the methodology of Gulland \& Rosenberg (1992) on the length based approaches to fish stock analyses published by the Food and Agricultural Organization (FAO). During each sampling day, random sub samples of fish were obtained from well mixed catches. The total length of fish was measured to the nearest centimetre. A minimum of 200 fish were measured on each sampling day except on occasions when the catches were low. 


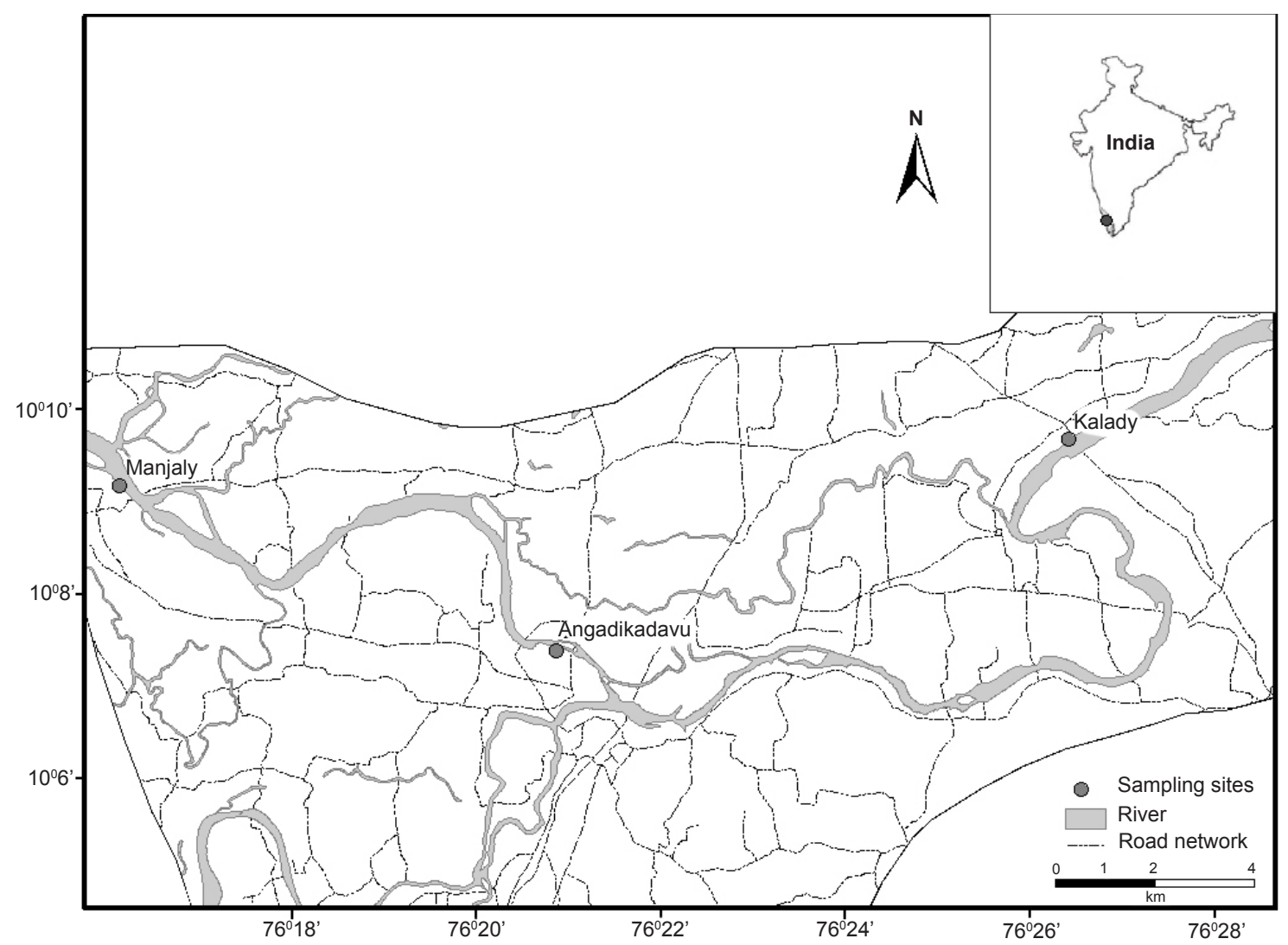

Figure 1. Map showing landing centres

Data obtained from the two sampling days in each month were later pooled and recognized as a 'monthly sample' (mean $219.83 \pm 18.60$ males and $281.83 \pm$ 26.95 females) by simple addition following AmaAbasi et al. (2004). This was done to avoid any bias in the data, as in some months there was a variation in the sample size obtained on the two different days.

\section{Data analysis}

Parameters a and $b$ in the length-weight relationship equation $\mathrm{W}=\mathrm{aL}^{\mathrm{b}}$ were estimated by least square regression after logarithmic transformation. Age and growth were estimated based on length-frequency data. It was assumed that the $H$. brachysoma growth conformed to the von Bertalanffy growth (VBG) model (von Bertalanffy 1938): $\mathrm{L}_{\mathrm{t}}=\mathrm{L}_{\infty}(1-\exp [-\mathrm{K}(\mathrm{t}$ $\left.\left.-\mathrm{t}_{0}\right)\right]$ ) where $\mathrm{L}_{\infty}$ is the asymptotic length (mm), $\mathrm{K}$ the growth constant $\left(\right.$ month $\left.^{-1}\right)$ and $\mathrm{t}_{0}$ time (months), when the theoretical length is zero. Growth parameters were obtained using the ELEFAN program (Pauly 1987) from the fitted curve with maximum goodness-of-fit $(\mathrm{Rn})$ index. The growth performance index (f) was computed according to Moreau et al. (1986) as $\varnothing=\log$
$\mathrm{K}+2 \log \mathrm{L}_{\mathrm{a}}$. Mortality coefficients, viz., total mortality $(\mathrm{Z})$, instantaneous natural mortality $(\mathrm{M})$, fishing mortality (F) and exploitation rate (E) were estimated using FiSAT program (Pauly 1980; Gayanilo \& Pauly 1997). Natural mortality was calculated using the empirical formula of Pauly (1980): In $\mathrm{M}=0.0152-$ $0.2791 \mathrm{n}_{\mathrm{a}}+0.65431 \mathrm{n} \mathrm{K}+0.4631 \mathrm{n} \mathrm{T}$. The exploitation rate was estimated using the formula $\mathrm{E}=\mathrm{F} / \mathrm{Z}$ (Gulland 1971). Although, we estimated the length-weight relationship as well as age for both males and females separately, the growth and mortality parameters were done only for the pooled populations. This was done so as to minimize any bias because of the difference in number of males and females obtained which may have influenced the results.

The probability of capture was estimated from the left ascending arm of length-converted catch curve. The right descending part of the catch curve was extrapolated backwards, such that the fish that ought to have been caught, had it not been for the effect of incomplete selection or recruitment, were added to those in the curve, with the ratio of expected numbers to those that were actually caught being used to 
estimate probabilities of capture. This method provides reasonable estimates of mean size at first capture $\left(\mathrm{L}_{\mathrm{c}}\right)$ (Hoydal et al. 1982; Jensen 1982). By plotting the cumulative probability of capture against mid-length, a resultant curve was obtained. From this curve the length at first capture $\mathrm{L}_{c}$ was taken as corresponding to the cumulative probability at $50 \%$. The entire lengthfrequency data was used to reconstruct the seasonal recruitment pattern of the fish by projecting backward all the restructured length-frequency data onto a 1-year time scale (Pauly 1987), along a trajectory defined by the computed VBG function. Then, using the maximum likelihood approach, the Gaussian distribution was fitted to the back-projected data through NORMSEP (normal separation) procedure (Hasselbald 1966).

The relative yield-per-recruit model of Beverton \& Holt $(1957,1966)$ as modified by Pauly \& Soriano (1986) and incorporated in the FiSAT program, was used to estimate the 'relative yield-per-recruit' $(Y / R)$ and 'relative biomass-per-recruit', assuming a selection ogive. The computed exploitation rate was compared with the expected values of $\mathrm{E}_{\max }$ (the value of exploitation rate giving maximum relative yield-per-recruit), E 0.1 (the value of $\mathrm{E}$ at which marginal increase in $\mathrm{Y} / \mathrm{R}$ is $10 \%$ of its value at $\mathrm{E}=0$ ) and $\mathrm{E} 0.5$ (the value of $\mathrm{E}$ at $50 \%$ of the unexploited relative biomass-per-recruit) (Sparre \& Venema 1992; Gayanilo \& Pauly 1997). The potential longevity of H. brachysoma was also calculated (Pauly \& Munro 1984): $\mathrm{T}_{\max }=3 / \mathrm{K}$.

The yield isopleths diagram was used to assess the impact on yield created by changes of exploitation rate $\mathrm{E}$ and the ratio of length at first capture to asymptotic length $\left(\mathrm{L}_{c} / \mathrm{L}_{\dot{\alpha}}\right)$ in relation to changes in mesh size. The optimum exploitation length $\left(\mathrm{L}_{\text {opt }}\right)$ was estimated from the empirical equation of Froese \& Binholan (2000).

\section{RESULTS}

\section{Length-Weight Relationship}

The length-weight relationship (LWR) of $H$. brachysoma males from the Periyar River was $\mathrm{W}=$ $0.0093 \mathrm{~L}^{3.072}(\mathrm{n}=51, \mathrm{r}=0.96, \mathrm{p}<0.01)$ and those for females was $\mathrm{W}=0.0079 \mathrm{~L}^{3.172}(\mathrm{n}=61, \mathrm{r}=0.98, \mathrm{p}<0.01)$. LWR of combined sexes was found to be $\mathrm{W}=0.0084$ $\mathrm{L}^{3.105}(\mathrm{n}=112, \mathrm{r}=0.972, \mathrm{p}<0.01)$. In all cases, the exponent of length-weight relationship $b$ was higher than 3 (males 3.072; females 3.127 and pooled 3.105) and the 95\% higher and lower confidence interval values were also above 3 indicating that the growth of $H$. brachysoma in river Periyar was isometric.

\section{Exploited stock}

The exploited population of $H$. brachysoma in Periyar during 2005 was constituted by individuals ranging from 112 to $340 \mathrm{~mm}$. The highest length class recorded among males was $280-300 \mathrm{~mm}$ while the same in female populations was $320-340 \mathrm{~mm}$. The fishery was dominated by individuals in the size range of 170 to $250 \mathrm{~mm}$ in both males and females. The size classes 200-220 mm and 240-260 mm (both 19\% each) constituted the largest share in males whereas in females it was the $240-260 \mathrm{~mm}$ size class (21\%) followed by $220-240 \mathrm{~mm}$ (17\%) size class. Sex ratio was $1: 1.3$ which was not significantly different from $1: 1(\mathrm{p}>0.05)$.

\section{Growth}

The growth parameters estimated in the male population of $H$. brachysoma from Periyar River are given in Table 1. The value of $\mathrm{t}_{0}$ as estimated by the empirical equation given by Pauly (1979) was found to be -0.0108 . The FiSAT output of restructured length frequency data of male population of $\mathrm{H}$. brachysoma in river Periyar with superimposed growth curve fitted with highest levels of Rn is given in Fig. 2. The VBGF for male $H$. brachysoma based on the growth parameters in the present study was expressed as: $\mathrm{L}_{\mathrm{t}}=388\left[1-\exp ^{-0.51(\mathrm{t}+0.0108)}\right]$. The lengths attained by male $H$. brachysoma following VBGF equation at the end of first, second, third and fourth years were estimated to be $156 \mathrm{~mm}, 249 \mathrm{~mm}, 304 \mathrm{~mm}$ and $338 \mathrm{~mm}$ respectively.

For the female population (Table 1), the value of $t_{0}$ was found to be -0.0103 . The FiSAT output of restructured length frequency data of female population of $\mathrm{H}$. brachysoma in Periyar River with superimposed growth curve fitted with highest levels of $\mathrm{Rn}$ is given in Fig. 3. The value of $t_{0}$ as estimated by empirical equation given by Pauly (1979) plot was found to be -0.0103 . The VBGF arrived at, based on the growth parameters in terms of female $H$. brachysoma, can be expressed as $\mathrm{L}_{\mathrm{t}}=400\left[1-\exp ^{-0.63(\mathrm{t}+0.0103)}\right]$. The lengths attained by female $H$. brachysoma following VBGF equation at the end of first, second, third and fourth 


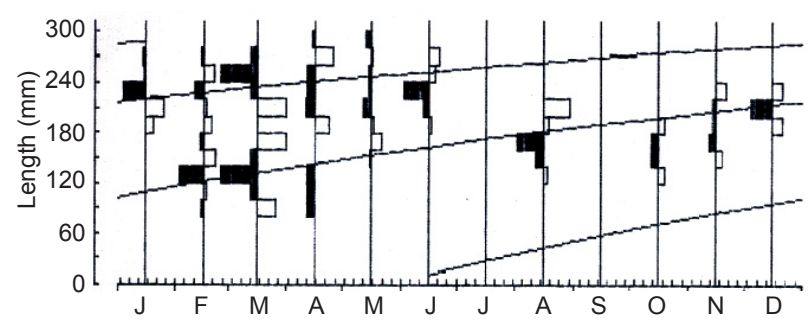

Figure 2. Growth curve of male population of Horabagrus brachysoma from River Periyar by ELEFAN 1 superimposed on the restructured length frequency diagram $\left(L_{\alpha}=388 \mathrm{~mm}, K=0.51 \mathrm{yr}^{-1}\right.$ and $\left.\mathrm{Rn}=0.325\right)$

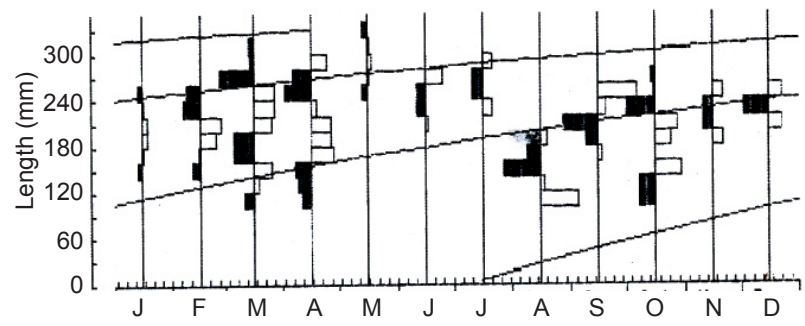

Figure 3. Growth curve of female population of Horabagrus brachysoma from River Periyar by ELEFAN 1 superimposed on the restructured length frequency diagram $\left(L_{\alpha}=400 \mathrm{~mm}, K=0.63 \mathrm{yr}^{-1}\right.$ and $\left.\mathrm{Rn}=0.314\right)$

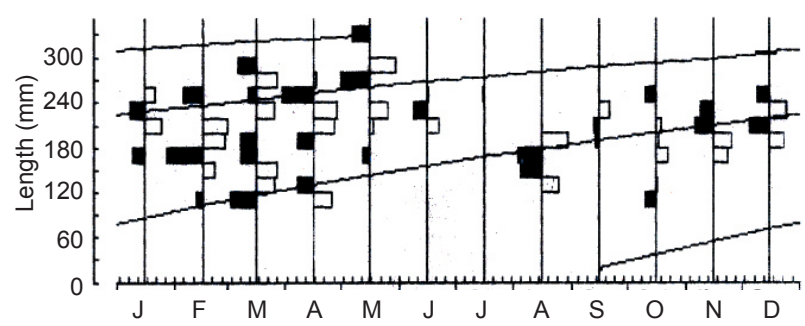

Figure 4. Growth curve of pooled population of Horabagrus brachysoma from River Periyar by ELEFAN 1 superimposed on the restructured length frequency diagram $\left(L_{\alpha}=422 \mathrm{~mm}, K=0.55 \mathrm{yr}^{-1}\right.$ and $\left.\mathrm{Rn}=0.255\right)$

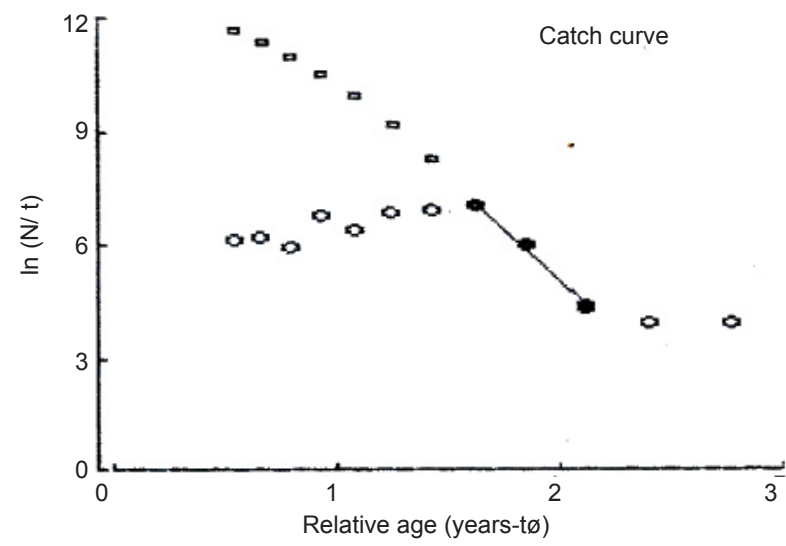

Figure 5. Length converted catch curve of pooled population of Horabagrus brachysoma in River Periyar ( $Z$ from catch curve $=5.64 ; M=1.04 ; F=4.60 ; E(F / Z)=0.82)$
Table 1. Growth parameters in male, female and pooled population of $\boldsymbol{H}$. brachysoma of Periyar River

\begin{tabular}{|l|c|c|c|c|}
\hline & $\mathbf{L}_{\alpha} \mathrm{mm}$ & K year $^{-1}$ & $\mathbf{R n}$ & $\boldsymbol{\varnothing}$ \\
\hline Male & 388 & 0.51 & 409 & 4.89 \\
\hline Female & 400 & 0.63 & 314 & 5.00 \\
\hline Pooled & 422 & 0.55 & 255 & 4.99 \\
\hline
\end{tabular}

years were estimated to be $188 \mathrm{~mm}, 287 \mathrm{~mm}, 340 \mathrm{~mm}$, $368 \mathrm{~mm}$ and $383 \mathrm{~mm}$, respectively.

For the pooled population (combined sexes), the value of $t_{0}$ was found to be -0.0115 . Fig. 4 provides the FiSAT output of restructured length frequency data of pooled population of $H$. brachysoma in Periyar River with superimposed growth curve fitted with highest levels of Rn. The VBGF in terms of pooled H. brachysoma population was expressed as $\mathrm{L}_{\mathrm{t}}=422$ $\left[1-\exp ^{-0.55(t+0.0115)}\right]$. The lengths attained by pooled $H$. brachysoma following VBGF equation at the end of one, two, three, four and five years were estimated to be $180 \mathrm{~mm}, 282 \mathrm{~mm}, 341 \mathrm{~mm}, 376 \mathrm{~mm}$ and $395 \mathrm{~mm}$, respectively.

\section{Mortality}

The FISAT output of mortality estimates of pooled population of $H$. brachysoma in Periyar River by catch curve method is depicted in Fig. 5. The total mortality (Z) was estimated to be $5.64 \mathrm{yr}^{-1}$ at a cut off length of $240 \mathrm{~mm}$. The estimates of natural mortality (M) were determined as $1.04 \mathrm{yr}^{-1}$. The values of fishing mortality coefficient $(\mathrm{F})$ and exploitation rate $(\mathrm{E})$ were worked out as $4.60 \mathrm{yr}^{-1}$ and $0.82 \mathrm{yr}^{-1}$, respectively. The optimum exploitation length $\left(\mathrm{L}_{\text {opt }}\right)$ was worked out as $259 \mathrm{~mm}$. Using the length converted catch curve method, the estimates of probabilities of capture were $\mathrm{L}_{25}=232 \mathrm{~mm}, \mathrm{~L}_{50}=260 \mathrm{~mm}$ and $\mathrm{L}_{75}=288 \mathrm{~mm}$ (Fig. 6) and the Lc was found to be $110 \mathrm{~mm}$. These values were subsequently used as inputs for relative $\mathrm{Y} / \mathrm{R}$ of Beverton \& Holt $(1957,1966)$. The $\mathrm{Lc} / \mathrm{L} \alpha$ and $\mathrm{M} / \mathrm{K}$ values used for $\mathrm{Y} / \mathrm{R}$ analysis were 0.2606 and 1.8909 respectively. The relative yield per recruit and biomass per recruit in H. brachysoma is presented in Fig. 7. The relative $\mathrm{Y} / \mathrm{R}$ reached a maximum at an exploitation rate of $0.5744 \mathrm{yr}^{-1}$ and thereafter decreased with an increase in the exploitation rate. It may be noted that the present exploitation rate $\mathrm{E}(0.82)$ has clearly exceeded the optimum exploitation rate of $\mathrm{E}_{\max }=0.5744$. The values of $\mathrm{E}_{0.1}$ and $\mathrm{E}_{0.5}$ were estimated as 0.5538 and 


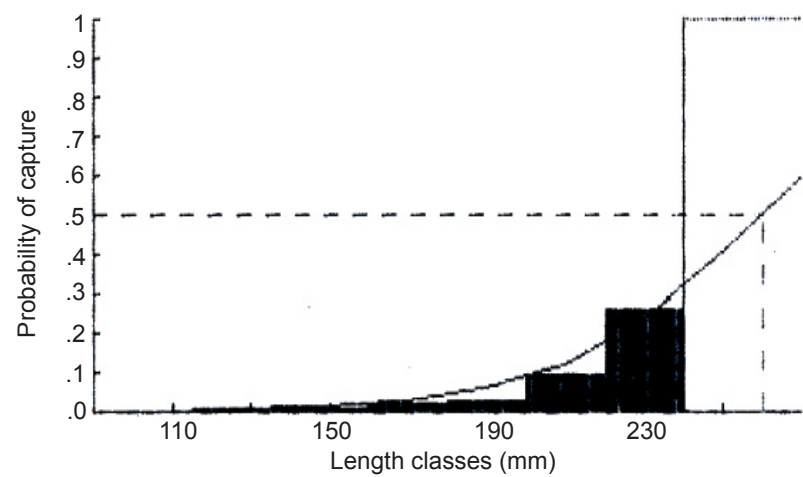

Figure 6. Probabilities of capture pattern of Horabagrus brachysoma from Periyar River

0.3333, respectively. The results of length-based virtual population analysis showed that $\mathrm{F}$ increases to a maximum of 2.7921 at a body size of $240-260 \mathrm{~mm}$ (Fig. 8). The catch increases substantially from 160 $180 \mathrm{~mm}$ size groups and attains maximum at 240-260 $\mathrm{mm}$.

\section{DISCUSSION}

\section{Length-Weight Relationship}

Exponential value of the length-weight relationship ' $\mathrm{b}$ ' in $H$. brachysoma from Periyar River followed the cubes law indicating an isometric growth pattern, similar to the observations made by Kumar et al. (1999) from Achenkovil and Ali et al. (2008) from Pampa rivers. Nevertheless, in Vembanad Lake, $H$.
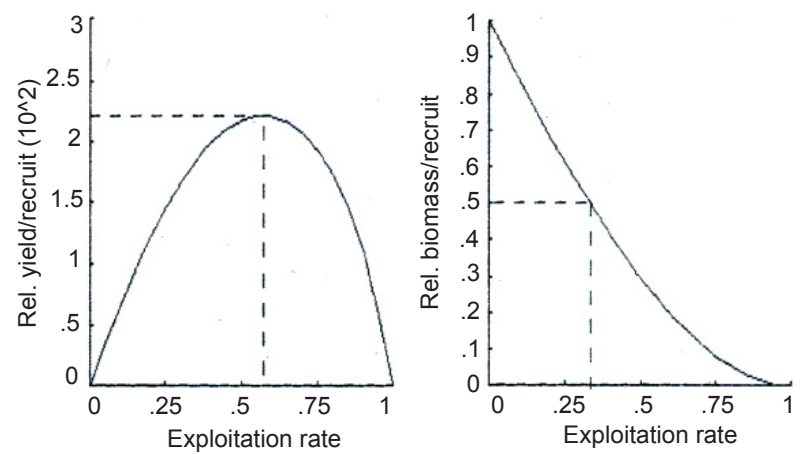

Figure 7. Relative yield per recruit and biomass per recruit of Horabagrus brachysoma from Periyar River $C_{L \alpha}=422 \mathrm{~mm}$; $\mathrm{L}_{c} / \mathrm{L}_{\alpha}=0.260$ and $\mathrm{M} / \mathrm{K}=1.89$ )

brachysoma showed an acute negative isometric growth pattern with ' $b$ ' values in the ranges of 1.7616 (for males) and 1.9441 (for females) (Prasad et al. 2005). This negative growth pattern of the Yellow Catfish in Vembanad Lake was attributed to the poor environmental conditions prevalent in the lake ecosystem, especially the high level of pollution coupled with poor availability of food items.

\section{Growth}

Horabagrus brachysoma is known to grow to a maximum size of $450 \mathrm{~mm}$ (Talwar \& Jhingaran 1991). However, the maximum size of this species that was obtained from the exploited stock in the Periyar during this study was $340 \mathrm{~mm}$. The dominant size class of $H$. brachysoma exploited from the river $(170-250 \mathrm{~mm})$ is more or less similar to those from

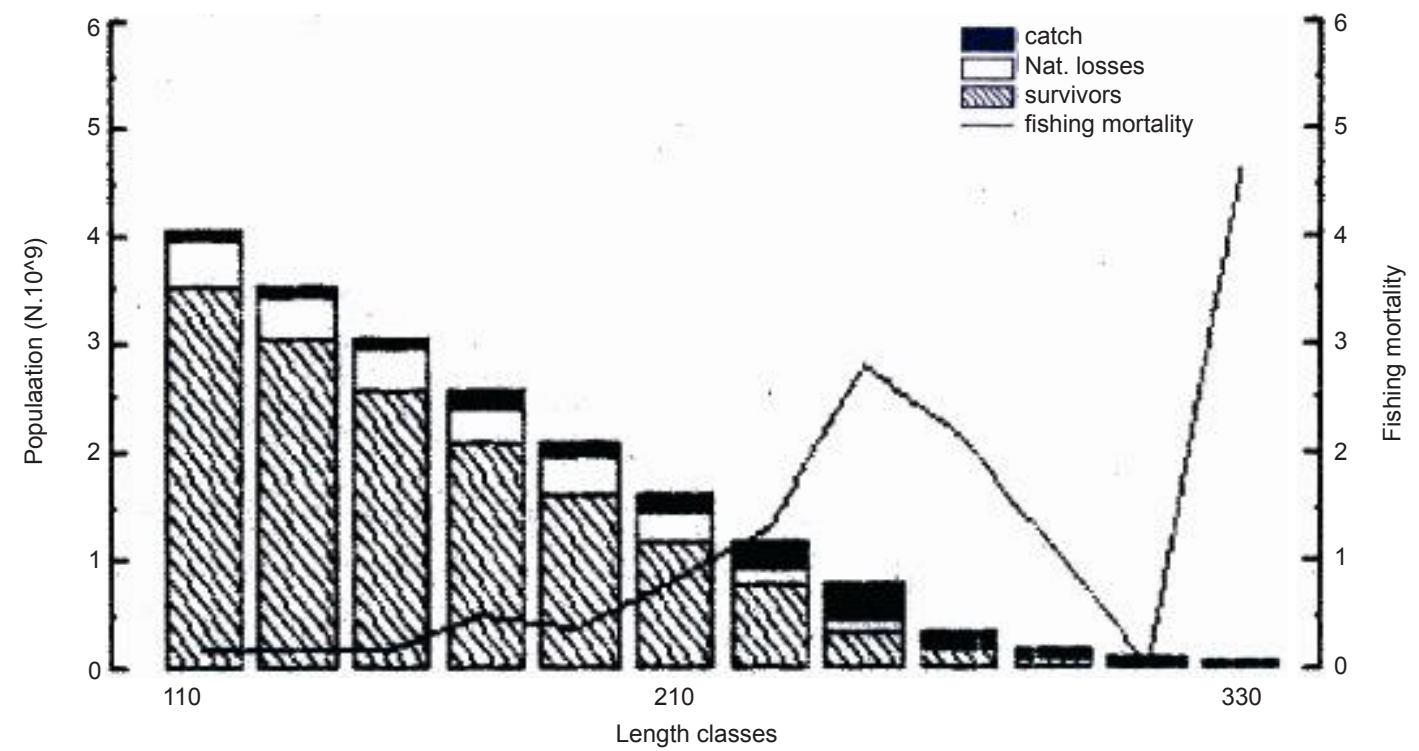

Figure 8. Length based virtual population analysis of Horabagrus brachysoma from Periyar River 
Vembanad Lake (160-300 mm) (Sreeraj et al. 2007). In general, $H$. brachysoma exploited from various parts of Kerala belonged to more or less the same size class. Assuming that the fish grows throughout its life, $\mathrm{L}_{\infty}$ is the largest theoretical mean length that it could attain in its natural habitat and $\mathrm{K}$ is the speed with which it grows towards this final size (Etim et al. 1999). Growth comparison is a multivariate problem that must take into consideration both the growth rate $(\mathrm{K})$ and the asymptotic size $\left(\mathrm{L}_{\dot{\alpha}}\right)$. Thus, we used the overall growth performance index ø (Pauly \& Munro 1984) as it meets these criteria, is easy to compute and exhibits the least variance when compared with other alternative indices. The growth performance index value (ø) of 4.99 observed in the present study is significantly higher than that obtained for many tropical freshwater catfish species including those belonging to the families Schilbeidae ( $\varnothing$ between 2.18 and 2.78) (Etim et al. 1999), Claroteidae $(\varnothing=2.32)$ (Abowei \& Davies 2009) and Synodontidae $(\varnothing=3.09)$ (Ofori-Danson et al. 2001). As phi prime ( $\varnothing^{\prime}$ ) is largely considered to be a species-specific parameter with their values being similar within related groups or taxa, the significantly high ø value observed for $H$. brachysoma is an interesting observation. The maximum size that H. brachysoma attains during its life is $422 \mathrm{~mm}$ and the life span estimated from the equation $\mathrm{t}_{\max }=3 / \mathrm{K}$ (Pauly 1983 ) is 5.45 years. The comparatively low life span and high growth performance index of $H$. brachysoma is uncharacteristic of freshwater catfishes, which are generally considered to be slow growing.

\section{Mortality}

The total mortality (Z) and natural mortality (M) of $H$. brachysoma in the Periyar River were computed as $5.64 \mathrm{yr}^{-1}$ and $1.04 \mathrm{yr}^{-1}$ respectively. Natural mortality being positively correlated with growth rates (Isaac \& Ruffino 1996) was higher in H. brachysoma when compared to slow growing species of catfish such as Clarotes laticeps (0.87) (Abowei \& Davies 2009), Schilbe intermedius (0.81) (Etim et al. 1999) and $S$. mystus (0.28) (Kolding et al. 1992). The exploitation rate (E) is an index used to assess if a stock is overfished, on the assumption that optimal value of $\mathrm{E}$ is equal to 0.5. Computed current exploitation rate $\mathrm{E}(0.82)$ is far higher than the optimum exploitation rate $\mathrm{E}_{\text {max }}(0.5744)$ indicating that $H$. brachysoma populations in Periyar River are being overexploited. Although the Yellow
Catfish has a longevity of 5.45 years, the exploited populations from river Periyar are constituted by the year 1 class. H. brachysoma in Periyar is therefore caught before they grow large enough to contribute substantially to the stock biomass, thus demonstrating growth fishing.

\section{Life history-exploitation relationship}

The size at first maturity for $H$. brachysoma in Periyar River was found to be $176.7 \mathrm{~mm}$ for females and 196mm for males (Chandran 2009). During the present study, it was observed that the exploited population of $H$. brachysoma in the Periyar during 2005 was constituted by individuals ranging in size from 112 to $340 \mathrm{~mm}$, and that the fishery was dominated by individuals in the size range 170 to 250 $\mathrm{mm}$ in both sexes. The fact that immature individuals of $H$. brachysoma are also fished out from the river indicates that recruitment fishing is taking place, damaging the reproductive potential and reducing the spawning stock of the species. Capture of small fish before they mature and breed is also known to lead to a reduction of fisher productivity and profit (Issac \& Ruffino 1996).

\section{Conservation and Management}

Currently the fishery for H. brachysoma in Periyar River appears to be unsustainable as is evident from the high rates of exploitation and the occurrence of growth and recruitment fishing. Such unsustainable exploitation levels of catfish in small-scale inland fisheries have been recorded from Volta Lake in Ghana with Hemisyondontis membranaceus (Ofori-Danson et al. 2001) and Cross River, Nigeria with S. intermidius (Etim et al. 1999). Being an open access fishery devoid of any management plan, the fishery for the endangered Yellow Catfish in Periyar is vulnerable to collapse if management interventions are not planned and put into practice in the immediate future.

Although regulating total harvest could be the single most important management strategy for protecting $H$. brachysoma stocks, implementation of a plan to reduce fishing effort in an artisanal subsistence fishery is nearly impossible. This is especially so in a region which has no history of any fisheries management in inland waters. Management strategies for $H$. brachysoma in Periyar should hence be based on a combination of different technical measures such 
as restrictions on gear, enforcement of size limits and implementation of closed seasons. In order to allow Yellow Catfish juveniles to reach sexual maturity before they are subjected to fishing mortality, a minimum size limit needs to be set at a size greater than the mean size at first reproduction. In the present scenario, a minimum catch size limit of $200 \mathrm{~mm}$ can be enforced so as to prevent recruitment overfishing. Setting of size limits should also be supplemented with restriction on the mesh size of the gill nets. Currently, the fishers in Periyar use set gill nets with mesh sizes between 25 and $80 \mathrm{~mm}$, resulting in the capture of small-sized juveniles that are below the size at maturity. A minimum mesh size of 160-180 mm should therefore, be mandatory for gill nets used by fishermen targeting $H$. brachysoma. If suitable gear restrictions are effectively implemented, there is little chance that the fishery will come in contact with the animals to be avoided (immature juveniles) (Charles 2001).

Another effective solution for the protection of H. brachysoma in Periyar can be through the use of closed seasons. Similar to the trawling ban (seasonal closure) which has been effectively enforced in the marine waters of Kerala for many years, a closed season starting from the month of May until August should be put into practice in the riverine system. These months are known to be the spawning seasons of $H$. brachysoma in the major rivers of Kerala including Periyar (Chandran 2009). This closed season will invariably safeguard the spawning process and bring to an end the capture of ripe females.

Management of riverine fisheries in Kerala has received little or no attention in the past with traditional fishing communities in Kerala often maintaining a relationship of conflict or accommodation with state institutions in fisheries management. Currently, there exists a lack of mutual trust between formal institutions and the traditional riverine fishing communities in Kerala. Formal institutional arrangements have lacked the participation as well as representation of traditional riverine fishing communities (Santha 2007). It is therefore apparent that this top-down and centralized decision making process has undermined the legitimacy and efficacy of fisheries management plans in the region. Therefore, only an organized effort involving the fisher communities can help in achieving success with the fisheries management plans that have been suggested for $H$. brachysoma in Periyar.

As in the case of $H$. brachysoma, it is also possible that other commercially important and threatened fish species such as Hypselobarbus curmuca, Hypselobarbus kolus and Tor khudree which are targeted by artisanal fishers in different reaches of the Periyar may also be under significant fishing pressures. Hence, studies need to be directed at assessing the dynamics of exploited populations of these threatened species for urgent management interventions. Smallscale fisheries have many features that make them vulnerable to collapse, including overfishing, excess capacity, distortions in markets, climate change (Andrew et al. 2007) and ineffective governance (Berkes et al. 2001). They have remained one of the most poorly understood fishery systems in the world, especially in developing countries. Management of resources in small-scale artisanal fisheries has remained a challenge worldwide, largely due to the scarcity of data on population, exploitation patterns and threats. The results of the current study - the first such work on the dynamics of an exploited fish population in a small-scale fishery in Kerala-could provide the much needed input for policy makers and government institutions in the region to develop and implement management strategies to improve equity and sustainability of freshwater artisanal fisheries in Kerala.

\section{REFERENCES}

Abowei, J.F.N. \& A.O. Davies (2009). Some population parameters of Clarotes laticeps (Rupell, 1829) from the freshwater reaches of Lower Nun River, Niger Delta, Nigeria. American Journal of Scientific Research 2: 10-19.

Ali, A., G. Prasad, L.R. Chandran, N.K. Balasubramaniam \& R. Raghavan (2008). Weight-length relationship of the Asian Sun Catfish Horabagrus brachysoma (Gunther, 1864) (Siluriformes: Horabagridae) from the Western Ghats rivers of Kerala, S. India. Acta Ichthyologica et Piscatoria 38: 41-44.

Ali, A., G. Prasad \& R. Raghavan (2007). Threatened fishes of the world: Horabagrus brachysoma (Gunther) (Bagridae). Environmental Biology of Fishes 78: 221

Allan, J.D., R. Abell., Z. Hogan, C. Ravenga, W.B. Taylor, R.L. Welcomme \& K. Winemiller (2005). Over fishing in inland waters. Bioscience 55: 1041-1051.

Ama-Abasi, D., S. Holzloehner \& U. Enin (2004). The dynamics of the exploited population of Ethmalosa fimbriata (Bowdich, 1825, Clupeidae) in the Cross river Estuary and 
adjacent Gulf of Guinea. Fisheries Research 68: 225-235.

Andrew, N.L., C. Bene, S.J. Hall, E.H. Allison, S.S. Heck \& B.D. Ratner (2007). Diagnosis and management of smallscale fisheries in developing countries. Fish and Fisheries 8: $227-240$

Anonymous (2002). Fisheries management for biodiversity conservation in the Brazilian Amazon. Final Report to the Darwin Initiative for the Survival of Species. Imperial College, London.

Baird, I.G. (2006). Probarbus jullieni and Probarbus labeamajor: the management and conservation of two of the largest fish species in the Mekong River in southern Laos. Aquatic Conservation: Freshwater and Marine Ecosystems 16: 517-532.

Berkes, F., R. Maho, P. McConney, R. Pollnac \& R. Pomeroy (2001). Managing Small-scale Fisheries: Alternative Directions and Methods. International Development Research Centre, Ottawa.

Beverton, R.J.H. \& S.J. Holt (1957). On The Dynamics of Exploited Fish Populations. Fisheries Investigation Series II. London 19, 533pp.

Beverton, R.J.H. \& S.J. Holt (1966). Manual of Methods for Fish Stock Assessment, Part II. FAO Fisheries Technical Paper No. 38 (Rev. 1), Rome: FAO, 67pp.

Bhatt, J.P., P. Nautiyal \& H.R. Singh (2000). Population structure of Himalayan Mahseer, a large cyprinid fish in the regulated foothill section of the river Ganga. Fisheries Research 44: 267-271.

Bhatt, J.P., P Nautiyal \& H.R. Singh (2004). Status (19931994) of the endangered fish Himalayan Mahseer Tor putitora (Hamilton) (Cyprinidae) in the mountain reaches of the river Ganga. Journal of Asian Fisheries Society 17: 341-355.

Bindu, L. (2006). Captive breeding protocols of two potential cultivable fishes, Etroplus suratensis (Bloch) and Horabagrus brachysoma (Gunther) endemic to the Western Ghat Region, Kerala. PhD Thesis. Mahatma Gandhi University, India, 215pp.

Chandran, R.L. (2009). Reproductive biology of Horabagrus brachysoma (Gunther 1864) and intrafamilial affinity of the family Horabagridae (Teleostei: Siluriformes) based on mitochondrial DNA markers. PhD Thesis. University of Kerala, 229pp.

Charles, A. (2001). Sustainable Fishery Systems. Fish and Aquatic Resources Series 5. Blackwell Science, Oxford.

de Graaf, S. (2003). The flood pulse and growth of flood plain fish in Bangladesh. Fisheries Management and Ecology 10: 241-247.

Dudgeon, D. (2000). Riverine biodiversity in Asia: a challenge to conservation biology. Hydrobiologia 418: 1-13.

Etim, L., P.E Lebo \& R.P. King (1999). The dynamics of an exploited population of a Siluroid Catfish (Schilbeintermedius Rupell 1832) in the Cross River, Nigeria. Fisheries Research 40: 295-307.

Froese, R. \& C. Binohlan (2000). Empirical relationships to estimate asymptotic length, length at first maturity and length at maximum yield per recruit of fishes, with a simple method to evaluate length-frequency data. Journal of Fish Biology 56: 758-773.

Froese, R. \& D. Pauly (2009). Fish Base. World Wide Web electronic publication. www.fishbase.org, version (07/2009).

Gayanilo, F.C. \& D. Pauly (1997). FAO-ICLARM Stock Assessment Tools: Reference Manual. FAO Computerized Information Series/Fisheries. No 8. Rome, 262pp.

Gulland, J.A. (1971). The fish resources of the Ocean West Polyfleet Survey. FAO Technical Paper. 97, 428pp.

Gulland, J.A. \& A.A. Rosenberg (1992). A review of lengthbased approaches to assessing fish stocks. FAO Fisheries Technical Paper No. 323, 100pp.

Hasselbald, V. (1966). Estimation of parameters for a mixture of normal distributions. Technometrics 8: 431-444.

Hoydal, K., C.J. Rorvik \& P. Sparre (1982). Estimation of effective mesh size and their utilization in assessment. Dana 2: 95-96.

Isaac, V.J. \& M.L. Ruffino (1996). Population dynamics of tambaqui, Colossoma macropomum Cuvier, in the lower Amazon, Brazil. Fisheries Management and Ecology 3: 315-333.

Jensen, A.L. (1982). Adjusting fishery catch curves for trawl selection using the logistics distribution. Journal of Conservation 40: 17-20.

Kolding, J., E.M. Tirasin \& L. Karenge (1992). Growth, mortality and length-weight parameters of fishes in Lake Kariba, Africa. NAGA, The World Fish Center Quarterly 15: $39-41$.

Kumar, G.S., T.V.A. Mercy \& K.C. John (1999). Lengthweight relationship in the catfish Horabagrus brachysoma (Gunther). Indian Journal of Fisheries 46: 191-193.

Kurup, B.M., T.G. Manojkumar \& K.V. Radhakrishnan (2006). Fish and Fisheries of Periyar Lake, Kerala. Indian Journal of Fisheries 53: 153-166.

Kurup, B.M., M.J. Sebastian, T.M. Sankaran \& P. Rabindranath (1993). Exploited fishery resources of Vembanad Lake - status of residents and migrants. Fishery Technology (Special Issue), Society of Fishery Technologists, (India) Kochi, India, 44-49pp.

Kurup, B.M., M.J Sebastian, T.M Sankaran \& P. Rabindranath (1995). Exploited fishery resources of Vembanad Lake - 4: Estimates of marketable surplus of production. Journal of the Marine Biological Association of India 37: 1-10

Maccord, P.F.L., R.A.M. Silvano, M.S. Ramire \& C.M. Begossi (2007). A dynamics of artisanal fisheries in two Brazilian Amazonian reserves: Implications to comanagement. Hydrobiologia 583: 365-376.

Molur, S. \& S. Walker (eds.) (1998). Report of the Workshop "Conservation Assessment and Management Plan for Freshwater Fishes of India". Zoo Outreach Organisation / Conservation Breeding Specialist Group, India,156pp

Moreau, J., C. Bambino. \& D. Pauly (1986). Indices of overall fish growth performance of 100 tilapia (Cichlidae) populations, pp. 201-206. In: Maclean, J.L., L.B. Dizon \& L.V. Hosillos (eds.). The First Asian Fisheries Forum. 
Manila, Philippines: Proceeding of the Asian Fisheries Society.

Ofori-Danson, P.K., C.J. Vanderpuye \& G.J. de Graaf (2001). Growth and mortality of the catfish, Hemisynodontis membranaceus (Geoffroy St. Hilaire), in the northern arm of Lake Volta, Ghana. Fisheries Management and Ecology 8: $37-45$.

Patra, M.K., S.K. Acharjee \& S.K. Chakraborty (2005). Conservation categories of siluroid fishes in North-East Sundarbans, India. Biodiversity and Conservation 14: 1863-1876

Pauly, D. (1979). Gill size and temperature as governing factors in fish growth: a generalization of von-Bertlanffy's growth formula. Berichte des Instituts fur Meereskunde an der Univ Kiel, No. 63 XV 156p.

Pauly, D. (1980). On the interrelationships between natural mortality, growth parameters, and mean environmental temperature in 175 fish stocks. Journal de Conseil, Conseil International Pour L'Exploration de la Mer 39: 175-192.

Pauly, D. (1983). Some simple methods for assessment pf tropical fish stocks. FAO Fisheries Technical Paper 234: $52 \mathrm{p}$.

Pauly, D. (1987). A review of ELEFAN system for analysis of length-frequency data in fish and aquatic invertebrates, pp. 7-34. In: Pauly D. \& G.R. Morgan (eds.). ICLARM Conference Proceedings on Length-based Methods in Fisheries Research, Vol. 13, ICLARM, Manila.

Pauly, D. \& S.K. Munro (1984). Once more on the comparison of growth in fish and invertebrates, ICLARM Fishbyte 2: 21

Pauly, D. \& M.L. Soriano (1986). Some practical extension to the Beverton and Holt's relative yield-per-recruit model, pp 491-496. In: MacLean, J.L., L.B. Dizon \& L.V. Hosillo (eds). The First Asian Fisheries Forum. Asian Fisheries Society, Manila, Philippines.

Prasad, G., R. Raghavan, N. Sreeraj \& A.P.H. Ali (2005). Biology, conservation and culture prospects of Horabagrus brachysoma an endangered Yellow Catfish from Vembanad Lake, Kerala (India). Sustain Fish 2005, International symposium on improved sustainability of fish production systems and appropriate technologies for utilization, Cochin University of Science and Technology, Kochi, India, 16-18 March 2005.

Raghavan, R. (2006). Yellow Catfish - a potential culture species in Southwestern India. Global Aquaculture Advocate June: 68-69.

Raghavan, R. \& A. Ali (2011). Horabagrus brachysoma. In: IUCN 2011. IUCN Red List of Threatened Species. Version 2011.2. <www.iucnredlist.org>. Downloaded on 17 February 2012.

Raghavan, R., A. Ali, N. Dahanukar \& A. Rosser (2011). Is the fishery for the Deccan Mahseer, Tor khudree (Sykes, 1839) in the Western Ghats Hotspot sustainable? A participatory approach to stock assessment. Fisheries Research 110: 29-38.

Santha, S.D. (2007). State interventions and natural resource management: a study on social interfaces in a riverine fisheries setting in Kerala, India. Natural Resources Forum 31: 61-70.

Smakhtin V., M. Arunachalam, S. Behera, A. Chatterjee, S Das, P. Gautam, G.D. Joshi., K.G. Sivaramakrishnan \& K.S. Unni (2007). Developing procedures for assessment of ecological status of Indian river basins in the context of environmental water requirements. Research Report 114, International Water Management Institute (IWMI), Battaramulla, Sri Lanka.

Sparre, P. \& S.C. Venema (1992). Introduction to tropical fish stock assessment. Part 1. Manual. FAO Fisheries Technical Paper No. 3061 Rev. 1, 376 pp

Sreeraj, N., R. Raghavan \& G. Prasad (2007). Some aspects of the fishery of the threatened Yellow Catfish, Horabagrus brachysoma, from Vembanad Lake with a note on their landings at Vaikom, Kerala, India. Zoos' Print Journal 22 (4): 2665-2666.

Talwar, P.K. \& A.G. Jhingran (1991). Inland fishes of India and Adjacent Countries-Vol. I \& II. Oxford \& IBH Publishing Co. Pvt. Ltd., New Delhi, 1158pp.

von Bertalanffy, L. (1934). Untersuchungen über die Gesetzlichkeit of Wachstums I. Allgemeine Grundlagen DER Theory; mathematische und physiologische Gesetzlichkeiten of Wachstums EIB Wassertieren. Arch. Entwicklungsmech 131: 613-652.

von Bertalanffy, L. (1938). A quantitative theory of organic growth. Human Biology 10: 181-213.

Wei, Q., F. Ke, J. Zhang, P. Zhuang., J. Luo, \& R. Zhou (1997). Biology, fisheries and conservation of sturgeons and paddlefish in China. Environmental Biology of Fishes 48: 241-255.

Author Details: G. PRASAD works on diversity, distribution and conservation of freshwater fishes and aquatic insects of the Western Ghats; ANVAR ALI is interested in research on taxonomy, biology and ecology of freshwater fishes; M. HARIKRISHNAN works on sustainable fisheries and aquaculture; RAJEEV RAGHAVAN is interested in research that addresses the connectivity between freshwater biodiversity, conservation and livelihoods in Western Ghats.

Author Contribution: GP, AA and RR designed the study; AA collected the data; $\mathrm{MH}$ analysed the data; RR and GP wrote the manuscript.

Acknowledgements: The study was funded by the Kerala State Science Technology and Environment Council (KSTEC), Government of Kerala, India. The authors thank the many local fishers of Kalady, Angadikkadavu and Manjaly for their help during the sampling. The authors are also grateful to the Subject Editor for providing inputs and suggesting necessary changes that greatly improved the manuscript. 